\title{
PENERAPAN MODEL PROBLEM BASED LEARNING BERBANTUAN PAPAN PECAHAN UNTUK MENINGKATKAN MINAT DAN HASIL BELAJAR MUATAN PELAJARAN MATEMATIKA SISWA KELAS 4 SD N KOPEK KECAMATAN GODONG
}

\author{
Yunita Patma Sari ${ }^{1}$, Wasitohadi ${ }^{2}$ \\ ${ }^{1}$ Pendidikan Guru Sekolah Dasar, Universitas Kristen Satya Wacana yunitapatmasari96@gmail.com \\ 2Pendidikan Guru Sekolah Dasar, Universitas Kristen Satya Wacana wasitohadiuksw@gmail.com
}

\begin{abstract}
INFO ARTIKEL
RiwayatArtikel:

Diterima: 20-03-2018

Disetujui: 05-04-2018
\end{abstract}

\section{Kata Kunci:}

Model PBL

Pecahan

Minat

Hasil Belajar

\section{ABSTRAK}

Abstrak: Penelitian ini merupakan Penelitian Tindakan Kelas (PTK). Penelitian ini bertujuan untuk meningkatkan minat dan hasil belajar muatan pelajaran Matematika siswa kelas IV SDN Kopek kecamatan Godong dengan menggunakan model Problem Based Learning (PBL) berbantuan papan pecahan. Subyek penelitian ini adalah kelas IV berjumlah 34 siswa terdiri dari 18 siswa laki- laki dan 16 siswa perempuan. Prosedur penelitian mengacu pada desain penelitian Kemmis dan Mc. Taggart yaitu mulai perencanaan, pelaksanaan, observasi dan refleksi. Kesimpulan penelitian ini adalah Model Pembelajaran Problem Based Learning berbantuan papan pecahan dapat meningkatkan minat dan hasil belajar peserta didik kelas IV SDN Kopek Kecamatan Godong Kabupaten Grobogan.

\begin{abstract}
This study is a Classroom Action Research (PTK). This study aims to increase interes and learning outcomes of Mathematics lesson students grade IV SDN Kopek Godong sub district by using a Problem Based Learning (PBL) model with fractional board. The subjects 0 this study were class IV of 34 students consisting of 18 male students and 16 female students The research procedure refers to the research design of Kemmis and Mc. Taggart that start: planning, execution, observation and reflection. The conclusion of this research is Problen Based Learning Learning Model with fractional board can increase interest and learning resul of fourth grade students of SDN Kopek Godong Sub-district Grobogan District.
\end{abstract}

\section{A. LATAR BELAKANG}

Sesuai dengan Permendikbud No. 65 tahun 2013 tentang Standar Proses, Kurikulum 2013 menggunakan pendekatan ilmiah (saintifik) sebagai pendekatan pokok yang perlu diperkuat dengan pembelajaran berbasis penyingkapan (Discovery Learning), pembelajaran berbasis penelitian (Inquiry Learning), dan pembelajaran berbasis proyek (project based learning). Keberhasilan pelaksanaan Kurikulum 2013 sangat ditentukan oleh keberhasilan guru dalam mengembangkan pembelajaran berdasarkan pendekatan atau model pembelajaran aktif tersebut.

Berdasarkan Undang- undang Nomor 20 Tahun 2003 tentang Sistem Pendidikan Nasional, taksonomi tersebut dikelompokkan dalam bentuk rumusan sikap, pengetahuan dan ketrampilan. Sesuai degan SKL (Standar Kompetensi Lulusan), sasaran dalam pembelajaran mencakup 3 pengembangan, yaitu pengembangan ranah sikap, pengembangan ranah pengetahuan dan pengembangan ranah ketrampilan. Untuk mengembangkan ketiga ranah tersebut, satuan pendidikan harus mengembangkannya sesuai dengan karakteristik peserta didiknya.

Undang- Undang Sistem Pendidikan Nasional Nomor 20 Tahun 2003 yang berisi Pendidikan nasional berfungsi mengembangkan kemampuan dan membentuk watak serta peradaban bangsa yang bermartabat dalam rangka mencerdaskan kehidupan bangsa, bertujuan untuk berkembangnya potensi peserta didik agar menjadi manusia yang beriman dan bertaqwa kepada Tuhan Yang Maha Esa, berakhlaq mulia, sehat berilmu, cakap, kreatif, mandiri, dan menjadi warga Negara yang demokratis serta bertanggung jawab. Menurut Bambang (2014: 165) Pendidikan adalah suatu cara pembentukan kemampuan manusia untuk menggunakan akal fikiran/ rasional mereka sebagai jawaban dalam menghadapi berbagai masalah yang timbul dimasa yang akan datang. Di era zaman modern sekarang kita harus menjadi manusia yang berpendidikan agar tidak tertinggal dengan kemajuan teknologi dan komunikasi. Untuk meningkatkan mutu pendidikan di sekolah perlu adanya kegiatan belajar mengajar. Proses kegiatan belajar mengajar merupakan kegiatan yang sanagat 
penting atau kegiatan inti dalam upaya meningkatkan kualitas pendidikan yang berdampak pada baik buruk jalannya suatu proses kegiatan belajar mengajar yang merupakan faktor dominan dalam menentukan kualitas pendidikan. Semua hasil belajar yang dicapai oleh peserta didik setelah dilakukannya kegiatan belajar mengajar merupakan tujuan dari pendidikan. Diharapkan peserta didik dapat mencapai tujuan pembelajaran sesuai dengan kurikulum yang berlaku pada setiap jenjang sekolah. Salah satu muatan pelajaran mulai dari Sekolah Dasar (SD) sampai di bangku kuliah adalah muatan pelajaran Matematika.

Peraturan Pemerintahan Republik Indonesia Nomor 19 Tahun 2005 BAB III pasal 7 ayat 3 diatur lebih lanjut dalam Lampiran Permendiknas Nomor 22 Tahun 2006 tentang Standar Isi, khususnya tentang muatan Matematika SD/MI. Matematika mempunyai peran penting dalam memajukan daya pikir manusia dan ilmu yang menjadi pondasi perkembangan teknologi modern. Mata pelajaran matematika perlu diajarkan kepada semua peserta didik mulai dari Sekolah Dasar hingga kejenjang perguruan tinggi untuk membekali peserta didik dengan kemampuanberfikir logis, analitis, sistematis, kritis, kreatif, cermat dan konsisten serta kemampuan bekerjasama (Depdiknas, 2006:9). Matematika adalah muatan pelajaran di sekolah yang dipandang penting dan dipelajari oleh setiap peserta didik mulai dari sekolah dasar hingga sekolah lanjutan tingkat atas dan bahkan perguruan tinggi. Menurut Supinah dan Titik (2010),pembelajaran matematika hendaknya dimulaidengan pengenalan masalah yang terkait dengan kehidupan nyata siswa, lalu siswa secarabertahap dibimbing untuk menguasai konsep matematika dengan melibatkan peran aktif siswadalam pembelajaran.Sarwono (Jaeng, 2004:3) menyatakan bahwa masih banyak siswa yang memperoleh hasil belajar yang kurang memuaskan sehingga matematika dianggap sebagai mata pelajaran yang cukup sulit bagi siswa. Hal ini terjadi karena banyak siswa yang belum memahami dan menguasai konsep- konsep dasar matematika. Penyebab utama pentingnya matematika adalah kemampuan siswa bermatematika merupakan landasan dan wahana pokok yang menjadi syarat mutlak yang harus dikuasai untuk dapat melatih siswa berpikir dengan jelas, logis, sistematis, serta memiliki kepribadian dan ketrampilan untuk menyelesaikan masalah dalam kehidupan sehari- hari.

Pernyataan di atas menandakan bahwa matematika adalah mata pelajaran yang sangat penting, karena matematika merupakan salah satu cara untuk mengembangkan kemampuan berpikir dan suatu pertanda intelegensi manusia. Oleh karena itu, matematika sangat diperlukan baik dalam kehidupan sehari-hari maupun untuk menghadapi kemajuan Ilmu Pengetahuan dan Teknologi (IPTEK). Meskipun sampai sekarang mata pelajaran matematika dianggap penting, namun matematika termasuk mata pelajaran yang dianggap sulit dipelajari bagi siswa dibandingkan dengan mata pelajaran lain. Karena matematika merupakan mata pelajaran yang berfokus pada peserta didik untuk bernalar, berpikir logis dan kritis dalam pemecahan masalah. Banyak anggapan bahwa matematika merupakan mata pelajaran yang sangat sulit, sehingga banyak peserta didik yang tidak menyukai matematika. Dengan demikian, banyaknya kegagalan peserta didik dalam matematika bukan terletak pada kurikulum yang salah, akan tetapi lebih pada cara dan teknik yang digunakan guru dalam kegiatan pembelajaran. Kurangnya variasi dalam teknik, model dan metode yang digunakan dalam kegiatan pembelajaran berdampak pada hasil belajar peserta didik yang kurang memuaskan.Hasil belajar atau bukti bahwaseseorang telah belajar ialah terjadinyaperubahan tingkah laku pada orangtersebut, misalnya dari tidak tahu menjaditahu, dan dari tidak mengerti menjadi mengerti (Hamalik, 2011). Sehubungan dengan masalah yang terjadi penyebab lainnya yaitu tentang model yang digunakan oleh seorang guru. Model pembelajaran sangat berpengaruh dalam menunjang keberhasilan proses belajar mengajar. Ada banyak model pembelajaran yaitu salah satunya adalah model pembelajaran Problem Based Learning (PBL).

Strategi Pembelajaran Berbasis Masalah (SPBM) dapat diartikan sebagai rangkaian aktivitas pembelajaran yang menekankan kepadaproses penyelesaian masalah yang dihadapi secara ilmiah (Sanjaya, 2007:214).Amir (mengutip rumusan Dutch,1994) yang menyatakan bahwa ProblemBased Learning merupakan metodeinstruksional yang menantang mahasiswaagar belajar untuk belajar, bekerjasamadalam kelompok untuk mencari solusi bagimasalah yang nyata (2009: 21). Sesuai dengan tujuan model Problem Based Learning adalah untukmenumbuhkan sikap ilmiah, dari beberapa bentuk model Problem Based Learning yang dikemukakan para ahli, maka secaraumum langkahlangkah model ProblemBased Learning sebagai berikut: 1)menyadari masalah, 2) merumuskanmasalah, 3) merumuskan hipotesis, 4)mengumpulkan data, 5) menguji hipotesis,6) menentukan pilihan penyelesaian(Sanjaya, 2006).

Berdasarkan hasil observasi dan wawancara dengan guru dan siswa di SD N Kopek Kecamatan Godong Kabupaten Grobogan membuktikan bahwa minat dan hasil belajar peserta didik kelas IV pada muatan pelajaran Matematika materi pecahan sangat rendah. Hal ini dikarenakan model pembelajaran yang digunakan guru belum tepat dan minat belajar siswa yang kurang. Selain itu kurangnya alat peraga dan media pembelajaran mengakibatkan peserta didik 
kurang menguasai atau memahami materi yang telah disampaikan oleh guru, sehingga berdampak pada minat dan hasil belajar peserta didik. Guru hanya menerangkan materi sedangkan siswa hanya bisa mendengarkan tanpa melakukan sesuatu, hal itu mengakibatkan siswa cepat lupa. Berbeda dengan halnya siswa melakukan, mempraktikan, mencaritahu sendiri konsep- konsep dasar matematika akan jauh lebih memahami dan mengingat apa yang telah disampaikan oleh guru. Teknik yang dilakukan oleh guru dalam mengajar sangat berpengaruh terhadap hasil belajar siswa. Apabila pada awal pembelajaran siswa diberi suatu masalah dan kemudian siswa harus mencari solusi atau siswa harus memecahkan masalah yang telah diberikan oleh guru secara individu maupun secara kelompok.Setiap proses belajar mengajar dibutuhkan alat peraga untuk mendukung tercapainya suatu pembelajaran. Melihat kondisi alat peraga di SD $\mathrm{N}$ Kopek Kecanatan Godong kabupaten Grobogan sangat kurang terutama untuk materi pecahan, maka dari itu peneliti akan melakukan penelitian dengan menggunakan papan pecahan untuk meningkatkan minat dan hasil belajar siswa. Hal ini dapat dilihat dari tabel 1.1 Ketuntasan hasil belajar muatan Matematika di bawah ini:

Tabel 1

Ketuntasan Hasil Belajar Muatan Pelajaran Matematika Kelas 4 SD N Kopek Kecamatan Godong Kabupaten Grobogan pada Pra siklus

\begin{tabular}{|c|c|c|}
\hline Frekuensi & Kategori & Persentase \\
\hline 5 & Sangat Baik & $8 \%$ \\
\hline 7 & Baik & $12 \%$ \\
\hline 8 & Cukup & $12 \%$ \\
\hline 14 & Kurang Baik & $56 \%$ \\
\hline 25 & & $100 \%$ \\
\hline Rata- rata hasil belajar siswa & 65,73 \\
\hline $\begin{array}{c}\text { Nilai terendah hasil belajar } \\
\text { siswa }\end{array}$ & 30 \\
\hline $\begin{array}{c}\text { Nilai tertinggi hasil belajar } \\
\text { siswa }\end{array}$ & 90 \\
\hline
\end{tabular}

Sesuai dengan masalah yang dihadapi siswa kelas IV SD N Kopek yaitu terdapat siswa yang belum mencapai Kriteria Ketuntasan Minimal (KKM) pada muatan pelajaran matematika yaitu 70. Melihat data yang diperoleh dari guru kelas IV yang berjumlah 34 siswa hanya 20 siswa yang dinyatakan tuntas dan siswa yang belum tuntas ada 14 siswa. Untuk kategori sangat baik ada 5 peserta didik atau setara dengan 14\%, peserta didik yang termasuk dalam kategori baik ada 7 pesrta didik atau setara dengan $20 \%$, peserta didik yang termasuk kategori cukup sebanyak 23\% atau setara dengan 8 peserta didik, dan ada 14 peserta didik atau sebanyak 43\%yang termasuk dalam kategori kurang baik atau belum mencapai KKM.

Berdasarkan wawancara dan hasil pengamatan di kelas IV SD N Kopek Kecamatan Godong menunjukan bahwa masih banyak siswa yang kurang berminat untuk belajar matematika. Hal tersebut dapat dilihat dari sikap dan tingkah laku siswa di dalam kelas yang sering main di kelas, berbicara dengan teman sebangku, berani berbicara di tempat duduk sedangkan diberi pertanyaan tidak mau menjawab dan apabila disuruh maju merasa malu dan tidak berani. Rendahnya minat belajar siswa disebabkan karena kurangnya media pembelajaran/ alat peraga dalam kegiatan belajar mengajar. Guru belum maksimal dalam menciptakan interaksi antara guru dengan siswa juga guru masih monoton dalam menyampaikan materi, sehingga banyak siswa yang merasa bosan dan tidak menyukai pelajaran matematika. Berikut adalah hasil minat belajar siswa sebelum dilakukannya siklus I dan siklus II di SD N Kopek Kecamatan Godong kabupaten Grobogan:

Tabel 2

Hasil minat belajar siswa kelas IV SD N Kopek Kecamatan Godong Kabupaten Grobogan pada Pra siklus

\begin{tabular}{|c|c|c|c|c|}
\hline \\
\hline No & Kategori & Interval & Frekuensi & Persentase \\
\hline 1 & $\begin{array}{c}\text { Kurang } \\
\text { Minat }\end{array}$ & $102-111$ & 20 & $59 \%$ \\
\hline 2 & Minat & $102-121$ & 5 & $15 \%$ \\
\hline 3 & $\begin{array}{l}\text { Sangat } \\
\text { Minat }\end{array}$ & $122-131$ & 9 & $26 \%$ \\
\hline \multicolumn{3}{|c|}{ Jumlah } & 34 & $100 \%$ \\
\hline
\end{tabular}

Berdasarkan masalah yang telah diuraikan di atas, maka akan dilakukan Penelitian Tindakan Kelas yang berjudul " Penerapan Model Problem Based Learning Berbantuan Papan Pecahan Untuk Meningkatkan Minat Dan Hasil Belajar Muatan Pelajaran Matematika Siswa Kelas 4 SD N Kopek Kecamatan Godong”.

\section{B. METODE PENELITIAN}

Penelitian Tindakan Kelas inidilaksanakan di SD N Kopek Kecamatan Godong Kabupaten Grobogan.Subyek penelitian yaitu kelas IV SD N Kopek berjumlah 34 siswa yang terdiri dari 18 siswa laki- laki dan 16 siswa perempuan.Penelitian dilaksanakan dalam 2siklus.Siklus 1 dilaksanakan pada tanggal 20 22 Maret 2018 dan siklus 2 dilaksanakan pada tanggal 27 - 29 Maret 2018. Prosedur penelitian ini mengacu pada desain penelitian Kemmis dan Mc. Taggart yaitu terdiri dari 4 tahap dimulai dengan perencanaan tindakan, pelaksanaan tindakan, observasi dan refleksi. Sebelum melakukan penelitian siklus 1 dan siklus 2 peneliti melakukan observasi terlebih dahulu yang bertujuan untuk mengetahui kondisi awalminat dan hasil belajar siswa kelas IV SD N Kopek terutama dalam pelajaran Matematika. Data pra siklus diperoleh dari hasil belajar siswa yang dilaksanakan guru dalam menjelaskan tanpa menggunakan alat peraga ataupun 
media yang mendukung kegiatan proses belajar mengajar.Teknik pengumpulan data dalam penelitian ini dilaksanakan dengan dua cara yaitu dengan teknik tes dan yeknik non tes.Teknik tes berupa soal pilihan ganda yang bertujuan untuk mengukur tingkat kemampuan siswa dalam menghitung pecahan dengan menggunakan Model Pembelajaran Problem Based Learning (PBL).Sedangkan teknik non tes yaitu berupa angketminat belajat siswa. Angket ini digunakan untuk mengukur minat yang dimiliki oleh siswa dalam mengikuti kegiatan pembelajaran matematika materi pecahan menggunakan alat peraga papan pecahan.Melalui penelitian ini dengan menggunakan Model Pembelajaran Problem Based Learning (PBL)berbantuan papan pecahan diharapkan akan meningkatkanminat dan hasil belajar siswa.Penelitian ini dinyatakan berhasil apabila minat siswa dalam mengikuti pembelajaran meningkat pada siklus I sebesar 70\%, dan pada siklus II sebesar 90\%. Sedangkan hasil belajar dalam menghitung pecahan meningkat $75 \%$ untuk siklus I dan 90\% untuk siklus II.

\section{HASIL DAN PEMBAHASAN \\ Pra SiKLUS}

Sebelum melakukan penelitian untuk siklus I dan sikuls II, peneliti melakukan observasi terlebih dahulu yang bertujuan untuk mengetahui kondisi awal minat dan hasil prestasi atau belajar siswa kelas IV SD N Kopek terutama dalam pelajaran Matematika. Dari hasil observasi dan wawancara diperoleh data yang menunjukkan bahwa minat dan tingkat keberhasilan siswa dalam muatan pelajaran Matematika masih sangat rendah. Hal ini dapat dilihat dari hasil belajar peserta didik yang masih banyak di bawah KKM (Kriteria Ketuntasan Minimal). Sedangkan minat belajar siswa juga masih sangat rendah, hal ini dapat dilihat dari angket yang telah diberikan kepada siswa yang menunjukkan kriteria minat yang sangat rendah. Berikut tabel yang menunjukkan hasil belajar siswa pra siklus:

Tabel 3

Ketuntasan Hasil Belajar Muatan Pelajaran Matematika Kelas 4 pada pra siklus

\begin{tabular}{|c|c|c|}
\hline Frekuensi & Kategori & Persentase \\
\hline 5 & Sangat Baik & $15 \%$ \\
\hline 7 & Baik & $21 \%$ \\
\hline 8 & Cukup & $23 \%$ \\
\hline 14 & Kurang Baik & $41 \%$ \\
\hline 34 & & $100 \%$ \\
\hline \multicolumn{2}{|c|}{ Rata- rata hasil belajar siswa } & 65,73 \\
\hline Nilai terendah hasil belajar siswa & 30 \\
\hline \multicolumn{2}{|c|}{ Nilai tertinggi hasil belajar siswa } & 90 \\
\hline
\end{tabular}

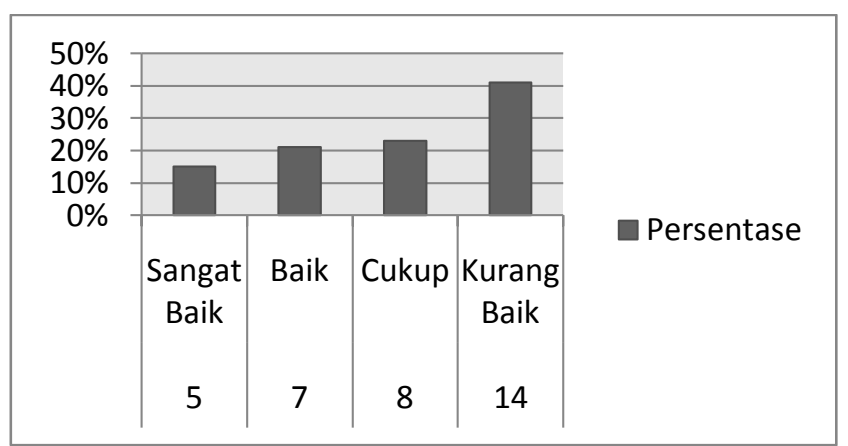

Gambar 1. Grafik ketuntasan hasil belajar matematika kelas IV SD N Kopek Kecamatan Godong Kabupaten Grobogan pada Pra Siklus

Dari data pra siklus di atas dapat dilihat bahwa masih banyak siswa yang mendapatkan nilai di bawah KKM yaitu ada 14 siswa atau sebanyak 41\% sedangkan siswa yang mendapatkan nilai di atas KKM sebanyak 59\% yaitu setara dengan 20 anak. Peneliti akan melakukan penelitian tindakan kelas yang bertujuan untuk meningkatkan hasil belajar siswa. Berikut tabel yang menunjukkan rendahnya minat belajar siswa pada muatan pelajaran matematika:

Tabel 4

Distribusi Frekuensi Minat Belajar Siswa Muatan Pelajaran Matematikakelas IV SD N Kopek Kecamatan Godong Kabupaten Grobogan Tahap Pra Siklus

\begin{tabular}{|c|c|c|c|c|}
\hline No & Kategori & Interval & Frekuensi & Persentase \\
\hline 1 & $\begin{array}{c}\text { Kurang } \\
\text { Minat }\end{array}$ & $102-111$ & 20 & $59 \%$ \\
\hline 2 & Minat & $102-121$ & 5 & $15 \%$ \\
\hline 3 & $\begin{array}{c}\text { Sangat } \\
\text { Minat }\end{array}$ & $122-131$ & 9 & $26 \%$ \\
\hline \multicolumn{3}{|c|}{ Jumlah } & 34 & $100 \%$ \\
\hline
\end{tabular}

Berdasarkan tabel di atas menunjukkan bahwa kategori kurang minat dengan interval $102-111$ ada 20 peserta didik atau setara dengan $59 \%$. Untuk kategori berminat dengan interval $112-121$ ada 5 peserta didik setara dengan $15 \%$. Sedangkan kategori sangat berminat dengan interval $122-131$ sebanyak 9 peserta didik setara dengan 26\%. Dari data di atas menunjukkan bahwa minat siswa terhadap pelajaran matematika sangat rendah. Maka perlu perbaikan pada siklus I baik itu perbaikan model pembelajaran ataupun adanya media pembelajaran atau alat peraga. Hal itu dilakukan agar rasa minat belajar siswa dapat tumbuh lagi menjadi lebih suka pelajaran matematika. Berikut adalah diagram batang yang menunjukkan bahwa kurangnya minat belajar siswa dalam pelajaran matematika: 


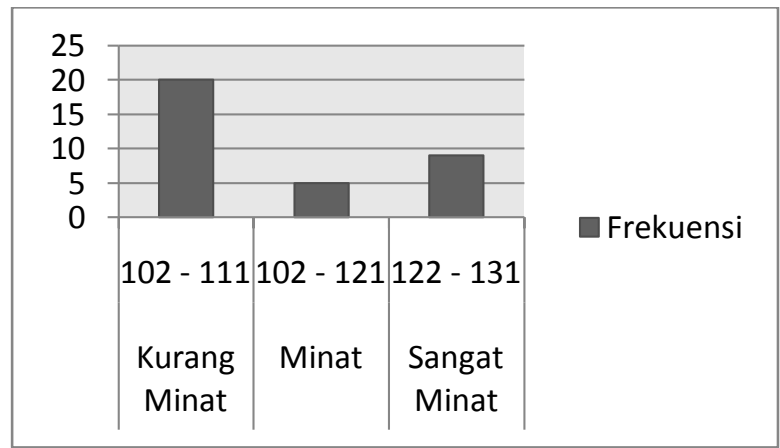

Gambar 2. Grafik ketuntasan minat belajar matematika kelas IV SD N Kopek Kecamatan Godong Kabupaten Grobogan pada Pra Siklus

Berdasarkan data hasil belajar siswa dan minat belajar siswa yang terbukti masih rendah maka perlu adanya perbaikan. Perbaikan yang dimaksud adalah dilakukannya penelitian tindakan kelas (PTK) dengan menggunakan model pembelajaran Problem Based Learning (PBL) berbantuan papan pecahan untuk meningkatkan minat dan hasil belajar muatan pelajaran matematika siswa kelas IV SD N Kopek Kecamatan Godong Kabupaten Grobogan. Penelitian dilakukan dalam 2 siklus, siklus I akan membahas pengertian pecahan, pengertian pecahan senilai, menuliskan bentuk pecahan, mengurutkan pecahan, dan menyederhanakan pecahan. Sedangkan siklus II membahas tentang membandingkan pecahan, penjumlahan dan pengurangan pecahan, serta memecahakan masalah pecahan dalam kegiatan seharihari.

\section{Siklus I}

Penelitian Siklus I pada tanggal 20 - 22 Maret 2018 pada muatan pelajaran matematika siswa kelas IV SD N Kopek Kecamatan Godong Kabupaten Grobogan. Pada penelitian ini, dimulai dengan kegiatan belajar mengajar dengan menggunakan Model Pembelajaran Problem Based Learning (PBL) berbantuan papan pecahan. Penelitian ini diamati oleh guru sebagai kolant dan ada teman sebaya sebagai observer. Observer bertugas untuk mengamati dan mengisi lembar observasi kegiatan pembelajaran baik kegiatan guru maupun kegiatan siswa. Hasil penelitian berfokus pada minat dan hasil belajar siswa dalam menghitung pecahan. Dari data pra siklus sampai siklus I menunjukkan bahwa adanya peningkatan hasil belajar mutan pelajaran matemtika siswa kelas IV SD N Kopek Kecamatan Godong Kabupaten Grobogan. Berikut tabel hasil belajar siswa muatan pelajaran matematika kelas IV SD N Kopek Kecamatan Godong Kabupaten Grobogan.

\section{Tabel 5}

\section{Ketuntasan Hasil Belajar Muatan Pelajaran} Matematika Kelas 4 pada Siklus I

\begin{tabular}{|c|c|c|}
\hline Frekuensi & Kategori & Persentase \\
\hline 8 & Sangat Baik & $23 \%$ \\
\hline
\end{tabular}

\begin{tabular}{|c|c|c|}
\hline Frekuensi & Kategori & Persentase \\
\hline 15 & Baik & $44 \%$ \\
\hline 5 & Cukup & $15 \%$ \\
\hline 6 & Kurang Baik & $\mathbf{1 8 \%}$ \\
\hline 34 & & $100 \%$ \\
\hline \multicolumn{2}{|c|}{ Rata- rata hasil belajar siswa } & 72,5 \\
\hline \multicolumn{2}{|c|}{ Nilai terendah hasil belajar siswa } & 45 \\
\hline \multicolumn{2}{|c|}{ Nilai tertinggi hasil belajar siswa } & 95 \\
\hline
\end{tabular}

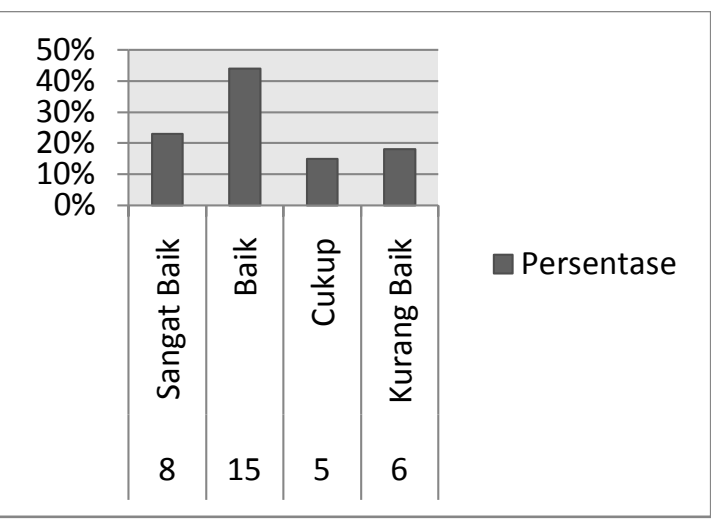

Gambar 3. Grafik ketuntasan hasil belajar matematika kelas IV SD N Kopek Kecamatan Godong Kabupaten Grobogan pada Siklus I

Dari data hasil penelitian pada siklus I yang telah disajikan dalam bentuk tabel dan grafik di atas dapat dilihat bahwa ada peningkatan hasil belajar siswa kelas IV SD N Kopek Kecamatan Godong kabupaten Grobogan. Pada saat pra siklus ada 14 peserta didik atau sebanyak $41 \%$ yang mendapatkan nilai di bawah KKM dan pada siklus I menurun menjadi 6 peserta didik atau sebanyak $18 \%$. Sedangkan peserta didik yang mendapatkan nilai di atas KKM yang semula ada 20 peserta didik atau sebanyak 59\% meningkat menjadi 28 setara dengan $82 \%$. Dari data siklus I menunjukkan bahwa adanya peningkatan hasil belajar peserta didik dalam menghitung pecahan. Tetapi, indikator pencapaian belum bisa dicapai secara maksimal. Untuk itu peneliti akan memperbaiki dan meningkatkan kemampuan siswa dalam memenuhi indiktor pencapaian dengan melakukan penelitian siklus II. Berikut tabel yang menunjukkan miant belajar siswa pada tahap siklus I:

Tabel 6

Hasil minat belajar siswa kelas IV SD N Kopek Kecamatan Godong Kabupaten Grobogan pada siklus I

\begin{tabular}{|c|c|c|c|c|}
\hline No & Kategori & Interval & Frekuensi & Persentase \\
\hline 1 & $\begin{array}{c}\text { Kurang } \\
\text { Minat }\end{array}$ & $102-111$ & 10 & $29 \%$ \\
\hline 2 & Minat & $102-121$ & 6 & $18 \%$ \\
\hline 3 & $\begin{array}{l}\text { Sangat } \\
\text { Minat }\end{array}$ & $122-131$ & 18 & $53 \%$ \\
\hline \multicolumn{3}{|c|}{ Jumlah } & 34 & $100 \%$ \\
\hline
\end{tabular}


Berikut adalah diagram batang yang menunjukkan bahwa kurangnya minat belajar siswa dalam pelajaran matematika:

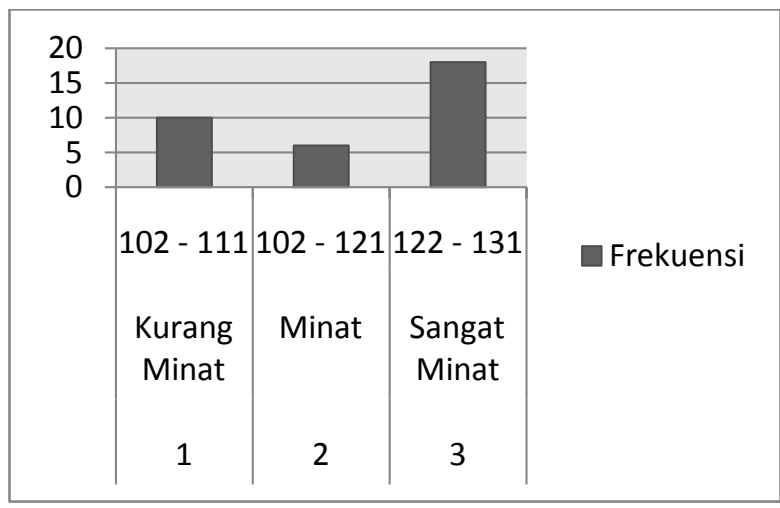

Gambar 4. Grafik ketuntasan minat belajar matematika kelas IV SD N Kopek Kecamatan Godong Kabupaten Grobogan pada Pra Siklus

Berdasarkan tabel minat belajar peserta didik terhadap pelajaran matematika di atas menunjukkan bahwa kategori kurang minat dengan interval $102-111$ ada 10 peserta didik atau setara dengan $29 \%$. Untuk kategori berminat dengan interval $112-121$ ada 6 peserta didik setara dengan $18 \%$. Sedangkan kategori sangat berminat dengan interval $122-131$ sebanyak 18 peserta didik setara dengan 53\%. Dari data di atas menunjukkan bahwa minat siswa terhadap pelajaran matematika masih kurang. Maka perlu perbaikan pada siklus II baik itu perbaikan model pembelajaran ataupun adanya media pembelajaran atau alat peraga.

\section{Siklus II}

Penelitian siklus II dilaksanakan pada tanggal 27-29 Maret 2018 kelas IV di SD N Kopek Kecamatan Godong Kabupaten Grobogan muatan pelajaran matematika dengan menggunakan Model Pembelajaran Problem Based Learning (PBL) berbantuan papan pecahan. Pelaksanaan penelitian siklus II masih sama dengan siklus I yaitu dibantu dengan teman sejawat sebagai observer dan guru sebagai pengamat penelitian. Pada siklus II ini guru berhasil menciptakan interaksi yang baik yaitu antara guru dengan siswa. Siswa juga berantusias dalam menggunkan alat peraga papan pecaha dalam pembelajaran matematika dalam materi pecahan. Dari data yang diperoleh pada siklus II dan sikap peserta didik dalam mengikuti pelajaran menunjukkan bahwa ada peningkatan minat dan hasil belajar siswa kelas IV SD N Kopek Kecamatan Godong Kabupaten Grobogan. Berikut tabel yang menunjukkan adanya peningkatan minat dan hasil belajar siswa dalam muatan pelajaran matematika:

\section{Tabel 7}

\section{Ketuntasan Hasil Belajar Muatan Pelajaran Matematika Kelas 4 pada Siklus II}

\begin{tabular}{|c|c|c|}
\hline Frekuensi & Kategori & Persentase \\
\hline 15 & Sangat Baik & $44 \%$ \\
\hline 14 & Baik & $41 \%$ \\
\hline 3 & Cukup & $9 \%$ \\
\hline 2 & Kurang Baik & $6 \%$ \\
\hline 34 & $100 \%$ \\
\hline Rata- rata hasil belajar siswa & 81,61 \\
\hline $\begin{array}{c}\text { Nilai terendah hasil belajar } \\
\text { siswa }\end{array}$ & 60 \\
\hline $\begin{array}{c}\text { Nilai tertinggi hasil belajar } \\
\text { siswa }\end{array}$ & 95 \\
\hline
\end{tabular}

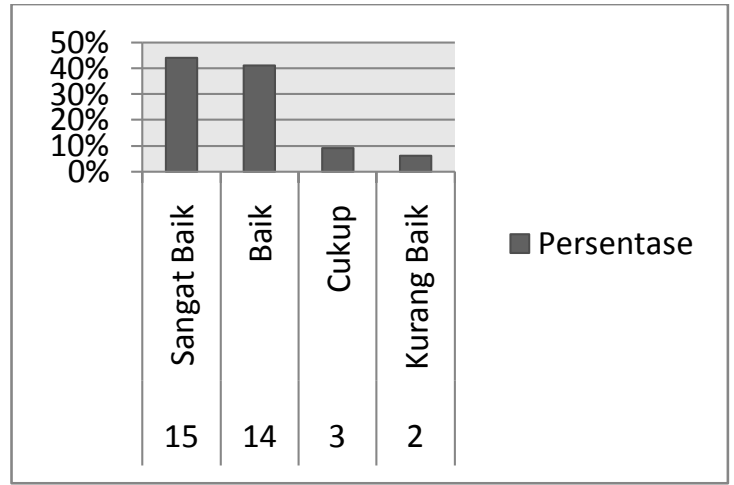

Gambar 5. Grafik ketuntasan hasil belajar matematika kelas IV SD N Kopek Kecamatan Godong Kabupaten Grobogan pada Siklus II

Dari tabel dan grafik di atas menunjukkan bahwa adanya peningkatan pada Siklus II. Peserta didik yang mendapatkan nilai di atas KKM sebanyak 94\% setara dengan 32 peserta didik dan sebanyak 6\% atau setara denga 2 peserta didik yang mendapatkan nilai di bawah KKM. Penelitian Tindakan Kelas ini belum sempurna, dikarenakan masih ada peserta didik yang mendapatkan nilai di bawah KKM yaitu sebanyak 2 peserta didik. Kedua peserta didik tersebut mendapatkan nilai di bawah KKM dikarenakan ada masalah pada IQ dan masalah kekeluargaan. Peserta didik yang mendapatkan nilai di bawah KKM mempunyai latar belakang ekonomi dan kurang mendapatkan perhatian dari keluarganya. Kedua orang tuanya bekerja di luar kota dan peserta didik tersebut tinggal bersama neneknya. Hal tersebut berdampak pada hasil belajar peserta didik.

\section{Tabel 8}

Hasil minat belajar siswa kelas IV SD N Kopek Kecamatan Godong Kabupaten Grobogan pada siklus II

\begin{tabular}{|c|c|c|c|c|}
\hline No & Kategori & Interval & Frekuensi & Persentase \\
\hline 1 & $\begin{array}{c}\text { Kurang } \\
\text { Minat }\end{array}$ & $102-111$ & 2 & $6 \%$ \\
\hline 2 & Minat & $102-121$ & 7 & $21 \%$ \\
\hline 3 & $\begin{array}{c}\text { Sangat } \\
\text { Minat }\end{array}$ & $122-131$ & 25 & $73 \%$ \\
\hline
\end{tabular}




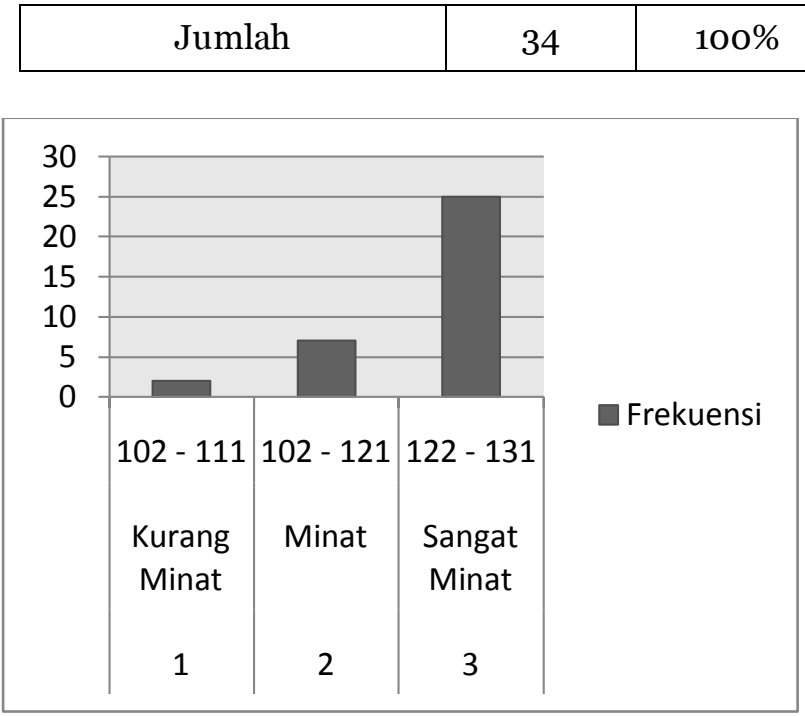

Gambar 6. Grafik minat belajar muatan pelajaran matematika kelas IV SD N Kopek Kecamatan Godong Kabupaten Grobogan pada Siklus II

Dari grafik di atas menunjukkan bahwa ada peningkatan minat belajar peserta didik dari pra siklus sampai dengan siklus II. Pada pra siklus peserta didik yang kurang minat dalam mengikuti pembelajaran matematika sebanyak $20 \%$ setara dengan 20 peserta didik meningkat menjadi $6 \%$ setara dengan 2 peserta didik. Untuk kategori berminat yang semula sebanyak $15 \%$ setara dengan 5 peserta didik meningkat menjadi 7 peserta didik setara dengan $21 \%$. Sedangkan peserta didik yang sangat berminat untuk mengikuti pelajaran matematika pada siklus II sebanyak $26 \%$ setara dengan 9 peserta didik meningkat menjadi $73 \%$ atau setara dengan 25 peserta didik.

\section{Pembahasan}

Penelitian Tindakan Kelas ini menerapkanModel Pembelajaran Problem Based Learning(PBL) berbantuan papan pecahan untuk siswa kelas IV SD N Kopek Kecamatan Godong Kabupaten Grobogan. Penelitian ini menggunakan model pembelajaran berbasis masalah yang bertujuan untuk meningkatkan minat dan hasil belajar siswa pada muatan pelajaran matematika materi pecahan. Model Pembelajaran Problem Based Learning mempunyai beberapa sintaks yaitu sebagai berikut (Warsono dan Hariyanto, 2012) : (1) Orientasi siswa pada masalah. Pada tahap ini guru dan siswa mempersiapkan pembelajaran yang akan dilakukan seperi alat tulis dan kesiapan siswa dalam mengikuti pembeljaran. Kemudian guru memberikan suatu permasalahan kepada siswa. (2) Mendefinisikan masalah dan mengorganisasikan siswa untuk belajar. Siswa dibantu guru dalam mendefinisikan dan mengorganisasikan tugas- tugas siswa dalam belajar memecahkan masalah, menentukan tema, jadwa, tugas dan lainnya. (3) Memandu investigasi mandiri maupun investigasi kelompok. Siswa diberikan motivasi oleh guru untuk membuat suatu hipotesis, mengumpulkan informasi, data yang relevan dengan tugas pemecahan masalah. Guru menugaskan siswa melakukan eksperimen untuk mendapatkan informasi agar masalah yang diberikan oleh guru da[at dipecahkan. (4) Mengembangkan dan mempresentasikan hasil karya. Siswa dibantu oleh guru dalam merencanakan dan menyiapkan hasil karya yang relevan misalnya membantu berbagi tugas dengan teman- teman sekelompoknya. (5) Refleksi dan Penilaian. Siswa dipandu oleh guru dalam melakukan refleksi, memahami kekuatan dan kelemahan laporan mereka dan teman yang lain diminta untuk menanggapinya. Mencatat hal- hal yang dianggap penting ataupun konsep matenatika yang terkait dalam pemecahan masalah dan siswa yang nelum paham dapat bertanya kepada guru. Dari langkah- langkah pembelajaran Problem Based Leraning di atas, peneliti menerapkannya di dalam langkah pembelajaran yang ada di RPP. Setiap Model Pembelajaran pasti mempunyai kelebihan dan kekurangan masing- masing. Berikut dipaparkan tentang kelebihan dan kekurang model pembelajaran Problem Based Learning: (1) Kelebihan model Problem Based Learning, yaitu sebagai berikut: (a) Pembelajaran Problem Based Learning mengembangkan kemampuan berpikir kritis siswa dalam memecahkan suatu masalah. (b) guru menjadi lebih kreatif dalam kegiatan pembelajaran (c) siswa menjadi terbiasa dalam menghadapi masalah (d) menumbuhkan motivasi, keberanian, rasa percaya diri, dan semangat siswa dapat memahami materi dengan baik. (2) Kekurangan Model pembelajaran Problem Based Learning yaitu: (a) Model Problem Based Learning diperlukan konsentrasi yang tinggi karena ada banyak hal- hal yang harus disiapkan oleh guru dalam penyajian kegiatan pembelajaran, (b) Memerlukan biaya dan tenaga yang tidak sedikit untuk diterapkannya model pembelajaran Problem Based Learning.Dari kelebihan dan kekurangan tersebut peneliti akan menggunkan model Problem Based Learning untuk melakukan Penelitian Tindakan Kelas di SD N Kopek Kecamatan Godong Kabupaten Grobogan.

Situasi dan kondisi kelas pada saat pra siklus di dapat hasil belajar dan minat belajar yang sangat kurang. Peneliti dapat menyimpulkan seperti itu karena sudah dilakukannya observasi dan wawancara di SD tersebut. Untuk itu peneliti melakukan penelitian ini dengan menerapkan II siklus. Berdasarkan hasil penelitian pada siklus I menunjukkan bahwa ada peningkatan dari pra siklus. Pada awalnya hasil belajar siswa pada pra siklus sebanyak 59\% setara dengan 20 peserta didik meningkat pada siklus I yaitu menjadi $82 \%$ atau 28 peserta didik yang mampu menghitung pecahan dan ada $41 \%$ setara dengan 14 peserta didik yang nilainya di bawah KKM menurun menjadi $18 \%$ 
atau setara dengan 6 peserta didik. Setelah data diperoleh pada siklus I yang menunjukkan ada 6 siswa yang masih di bawah KKM, peneliti meakukan perbaikan pada siklus II yang bertujuan untuk meningkatkan hasil dan minat belajar peserta didik. Pada siklus II terdapat peningkatan hasil belajar peserta didik kelas IV SD N Kopek Kecamatan Godong Kabupaten Grobogan walaupun itu belum sempurna. Pada siklus I terdapat $18 \%$ setara dengan 6 peserta didik yang masih di bawah KKM menurun menjadi $6 \%$ atau setara dengan 2 peserta didik. Sedangkan $82 \%$ pada siklus 1 peserta didik yang mampu menghitung pecahan meningkat menjadi 94\% atau setara dengan 32 peserta didik. Berikut grafik yang menunjukkan adanya peningkatan dari pra siklus ke siklus I dan Siklus I ke Siklus II:

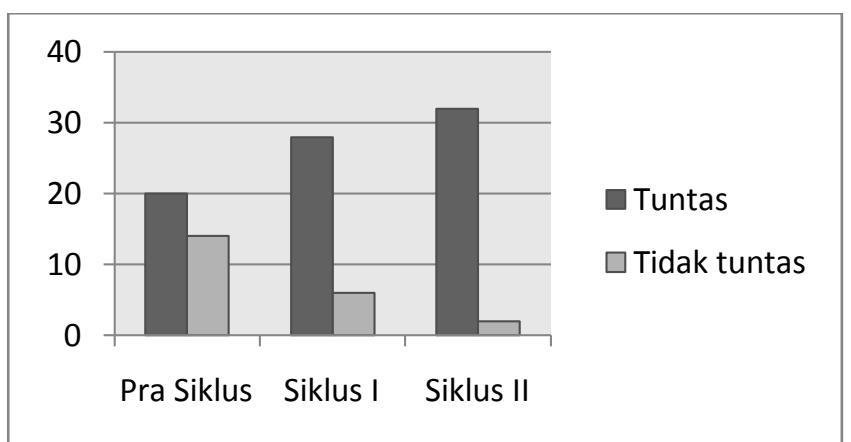

Gambar 7. Grafik persentase hasil belajar siswa kelas IV SD N Kopek Kecamatan Godong Kabupaten Grobogan muatan pelajaran matematika

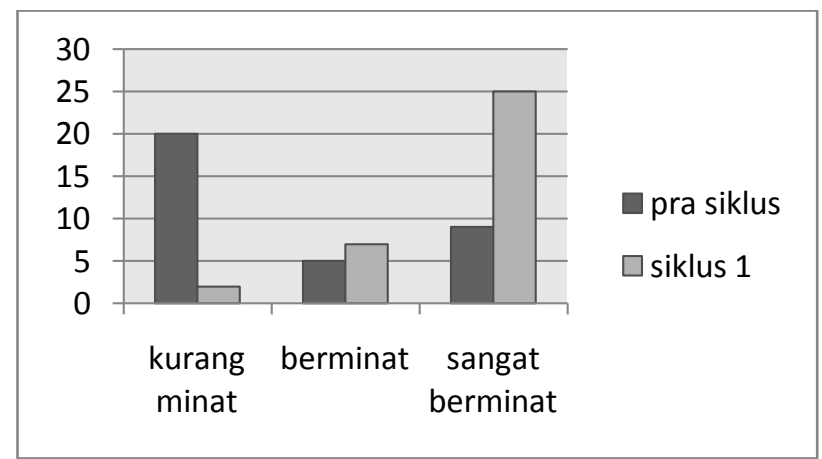

Gambar 8. Grafik minat belajar siswa kelas IV SD N Kopek Kecamatan Godong Kabupaten Grobogan muatan pelajaran matematika

Dengan dimikian model pembelajaran Problem Based Learning (PBL) berbantuan papan pecahan pada muatan pelajaran matematika terbukti dapat meningkatkan minat dan hasil belajar peserta didik kelas IV SD N Kopek Kecamatan Godong Kabupaten Grobogan.

\section{SIMPULAN DAN SARAN}

Berdasarkan pembahasan dan hasil penelitian yang telah dipaparkan diatas, maka dapat disimpulkan bahwa (1) Langkah - langkah pembelajaran menggunakan Model Problem Based Learning berbantuan papan pecahan terbukti dapat meningkatkan minat dan hasil belajar siswa kelas IV SD N Kopek Kecamatan Godong Kabupaten Grobogan. (2) Minat belajar siswa meningkat dengan menggunakan Model Pembelajaran Problem Based Learning berbantuan papan pecahan dalam muatan pelajaran matematika kelas IV SD N Kopek Kecamatan Godong Kabupaten Grobogan. (3) Hasil belajar siswa terbukti meningkat dengan menggunakan Model Pembelajaran Problem Based Learning berbantuan papan pecahan dalam muatan pelajaran matematika kelas IV SD N Kopek Kecamatan Godong Kabupaten Grobogan.

Sesuai dengan kesimpulan yang telah dijelaskan di atas ada beberapa saran untuk guru, siswa, dan peneliti lain. Untuk guru dapat menggunkan Model Pembelajaran Problem Based Learning dengan dilengkapi alat peraga (papan pecahan) untuk materi pecahan agar memudahkan guru dalam menyampaikan materi. Bagi siswa seharusnya dapat menghargai guru yang di depan dan mendengarkan guru saat menyampaikan materi dengan menggunakan papan pecahan. Sedangkan untuk peneliti lebih kreatif dalam membuat indikator tingkat berpikir siswa dan lebih kreatif dalam membuat alat peraga.

\section{UCAPAN TERIMA KASIH}

Penulis mengucapkan banyak terima kasih kepada: Bapak Dr. Wasitohadi, M.Pd selaku dosen pembimbing yang telah membimbing penulis hingga dapat menyelesaikan jurnal ini.

Kepala Sekolah, Bapak dan Ibu guru yang mengajar di SD N Kopek Kecamatan Godong Kebupaten Grobogan yang telah mengizinkan penulis untuk melakukan penelitian di SD tersebut.

\section{DAFTAR RUJUKAN}

(1) Kemdibud. 2013. Pengembangan Kurikulum 2013. Paparan Mendikbud dalam Sosialisasi Kurikulum 2013. Jakarta: Kemdikbud

(2) Supinah dan Titik S. 2010. Modul Matematika SD Program Bermutu, Pembelajaran Berbasis Masalah Matematika di SD/MI. Kemdiknas, Yogyakarta

(3) Warsono \& Hariyanto. (2012).Pembelajaran Aktif: Teori danAsesmen. Bandung: PT RemajaRosdakarya

(4) Agustian, Vivin N. 2013. Peningkatan aktivitas dan hasil belajar siswa melalui Model Problem Based Learning (PBL). Journal of Elementary Education, no. 2 vol. 1

(5) Sanjaya, W. 2007. Strategi Pembelajaran Berorientasi Standar Proses Pendidikan. Jakarta: Kencana Prenada Media Group.

(6) Fadly, Aditya. 2012. Peningkatan Aktivitas dan Hasil Belajar Siswa melalui Model Pembelajaran Problem Based Learning (PBL) di SMK Ardjuna 1 Malang. Jurnal. 1-15 
174 PENDEKAR | Jurnal Pendidikan Berkarakter | Vol. 1, No. 1, April 2018 (Special Issues), hal. 166-174

(7) Hamalik, O. (2011). Proses BelajarMengajar. Jakarta: PT Bumi Aksara

(8) Amir, M. T. (2009). Inovasi PendidikanMelalui Problem Based Learning:Bagaimana PendidikMemberdayakan Pemelajar di EraPengetahuan. Jakarta: PrenadaMedia Group

\section{PROFIL PENULIS UTAMA}

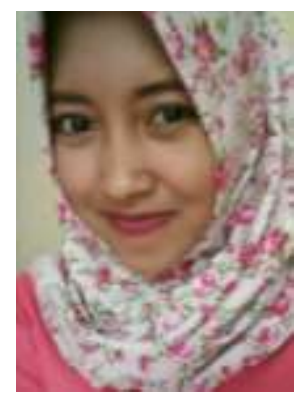

Nama penulis "Yunita Patma Sari" mahasiswa Pendidikan Guru Sekolah dasar (PGSD) Fakultas Keguruan dan Ilmu Pendidikan (FKIP) Universitas Kristen Satya Wacana (UKSW). Tempat tanggal lahir Grobogan, 30 Juni 1996. Alamat Dusun Pondok rt/rw 01/o7 Desa Plosoharjo Kecamatan Toroh Kabupaten Grobogan. Penulis anak ke 3 dari 3 berasudara yang semuanya perempuan. Pendidikan dimulai dari TK Dharma Wanita 3 Plosoharjo tahun 1999 - 2002 dan kemudian naik kelas 1 di SD N 3 Plosoharjo tahun 20022008. Setelah itu penulis melanjutkan pendidikan di SMP N 1 Toroh pada tahun 2008 - 2011. Selanjutnya sekolah di MAN 1 Grobogan pada tahun 2011 - 2014. Kemudian melanjutkan kuliah mengambil jurusan Program Studi Pendidikan Guru Sekolah Dasar (PGSD), Fakultas Keguruan dan Ilmu Pendidikan (FKIP) di Universitas Kristen Satya Wacana pada tahun 2014 sampai sekarang. Apabila ada kritik atau saran dapat dikirm di alamat email yunitapatmasarig6@gmail.com. 